\title{
PENGARUH KOMPETENSI KOMITE AUDIT, AKTIVITAS KOMITE AUDIT DAN KEPEMILIKAN INSTITUSIONAL TERHADAP MANAJEMEN LABA
}

\begin{abstract}
The objective of this study is to analyze the influence of audit committee and institutional ownership on earnings management. The characteristics that used to measure the effectiveness of the audit committee competence, and audit committee activity. Institutional ownership is measured by the number of proportion of shares held by institutional shareholders divided by the number of shares issued. Earnings management in this study were measured by using the value of discretionary accrual. The population in this study is manufacturing companies listed on the Indonesia Stock Exchange (BEI) in 2007-2012. Based on purposive sampling method, the number of samples in this study of 300 samples. Testing the hypothesis using multiple regression analysis. The results of hypothesis testing indicate that audit committee competence and audit committee activity had a significant negative effect on earnings management. Instead institutional ownership had not influence on earnings management.
\end{abstract}

Keywords : earnings management, audit committee, insitutional ownership.

\section{PENDAHULUAN}

Semua elemen dalam laporan keuangan pada dasarnya merupakan media yang diperlukan untuk pertanggungjawaban manajemen. Namun demikian, perhatian investor lebih sering terpusat pada informasi laba tanpa memperhatikan prosedur yang digunakan untuk menghasilkan informasi laba tersebut (Beattie, et al., 1994). Hal ini disebabkan informasi laba atau laba historis berguna untuk mengukur efisiensi manajemen, membantu memprediksi keadaan usaha dan distribusi dividen dimasa yang akan datang, mengukur keberhasilan manajemen, serta sebagai acuan pengambilan keputusan ekonomis di masa yang akan datang (Hendriksen dan Van Breda, 1992). Kecenderungan investor dan pihak eksternal lainnya yang lebih berfokus pada informasi laba, memicu manajemen melakukan disfunctional behaviour berupa manajemen laba (earnings management) atau manipulasi laba (earnings manipulation) untuk menghasilkan laba yang dianggap normal bagi suatu perusahaan (Bartov,1993).

Upaya untuk merekayasa atau memanipulasi laba tersebut dapat terjadi karena metode akuntansi memberi peluang bagi manajemen untuk melibatkan unsur subyektifitas dalam membuat estimasi-estimasi (Worthy, 1984). Perilaku memanipulasi laba ini juga timbul karena adanya asimetri informasi (information asymmetri) yang tinggi antara manajemen dengan pihak lain yang tidak mempunyai sumber atau akses informasi yang memadai untuk memonitor tindakan manajemen (Richardson,1998). Akibatnya, manajemen akan berusaha memanipulasi laporan kinerja perusahaan untuk kepentingannya sendiri (Morris, 1987).

Terjadinya skandal keuangan di beberapa perusahaan, merupakan kegagalan integritas laporan keuangan untuk memenuhi kebutuhan informasi para pengguna laporan. Laba sebagai bagian dari laporan keuangan tidak menyajikan fakta yang sebenarnya tentang kondisi ekonomi perusahaan sehingga laba yang diharapkan

Korespondensi dengan penulis:

66 Metta Kusumaningtyas \& Dessy Noor Farida

Fakultas Ekonomi STIE Bank BPD Jateng 
dapat memberikan informasi untuk mendukung pengambilan keputusan menjadi diragukan kualitasnya. Jika informasi yang disampaikan dapat memenuhi kebutuhan stakeholders, maka praktik manajemen laba dapat diminimalkan (Boediono, 2005).

Adanya kegagalan beberapa perusahaan dan timbulnya malpraktik keuangan tersebut menunjukkan buruknya praktik corporate governance (Sabeni, 2005). Good corporate governance diperlukan untuk mendorong terciptanya pasar yang efisien, transparan dan konsisten dengan peraturan perundang-undangan. Penerapan good corporate governance perlu didukung oleh tiga pilar yang saling berhubungan, yaitu negara dan perangkatnya sebagai regulator, dunia usaha sebagai pelaku pasar, dan masyarakat sebagai pengguna produk dan jasa dunia usaha.

Pelaksanaan corporate governance di Indonesia dalam hal regulatory framework, untuk mengkaji peraturan perundang-undangan yang terkait dengan korporasi dan program reformasi hukum, pada umumnya terdapat beberapa capaian yang terkait dengan implementasi good corporate governance seperti diberlakukannya undang-undang tentang Bank Indonesia di tahun 1998, undang-undang anti korupsi tahun 1999, dan undang-undang BUMN, serta privatisasi BUMN tahun 2003 (Kaihatu, 2005). Dalam kaitan dengan peran dan fungsi tersebut, BAPEPAM dapat memastikan bahwa berbagai peraturan dan ketentuan yang ada, terus menerus disempurnakan, serta berbagai pelanggaran yang terjadi akan mendapatkan sanksi sesuai ketentuan yang berlaku. BAPEPAM secara langsung maupun tidak langsung telah mendorong implementasi prinsip-prinsip good corporate governance di Indonesia, dengan menerbitkan peraturan dan kebijakan yang terkait dengan good corporate governance. Menurut Surat Keputusan Menteri Negara/Kepala Badan Penanaman Modal dan pembinaan BUMN No. 23/M-PM.PBUMN/2000 tentang pengembangan praktik good corporate governance dalam perusahaan perseroan (PERSERO), good corporate governance adalah prinsip korporasi yang sehat yang perlu diterapkan dalam pengelolaan perusahaan yang dilaksanakan semata-mata demi menjaga kepentingan perusahaan dalam rangka mencapai maksud dan tujuan perusahaan.

Upaya untuk menjalankan good corporate governance yang tepat di perusahaan, diperlukan adanya sistem pengawasan yang dilakukan oleh dewan komisaris. Secara umum, dewan komisaris melakukan fungsi pengawasan melalui komite-komite dengan tujuan untuk menggunakan waktu yang efisien dan memanfaatkan keahlian individu masing-masing direkturnya. Peran komite audit sebagai komite penunjang tugas dewan komisaris adalah membantu dewan komisaris untuk memastikan bahwa, (a) laporan keuangan disajikan secara wajar sesuai dengan prinsip akuntansi yang berlaku umum, (b) struktur pengendalian internal perusahaan dilaksanakan dengan baik, (c) pelaksanaan audit internal maupun eksternal dilaksanakan sesuai dengan standar audit yang berlaku, dan (d) tindak lanjut temuan hasil audit dilaksanakan oleh manajemen.

Penelitian yang dilakukan oleh Chtourou et al. (2001); Xie, et al. (2003); Bedard, et al. (2004); Carcello et al. (2006), menemukan bahwa komite audit yang mempunyai keahlian di bidang keuangan, berpengaruh negatif terhadap manajemen laba. Yang dan Krishnan (2005); Lin et al. (2006), tidak menemukan hubungan yang signifikan dalam aktivitas komite audit dengan manajemen laba.

Selain peran komite audit, kepemilikan institusional merupakan bagian lain dari corporate governance, karena institusi mempunyai sumber daya, kemampuan dan kesempatan untuk memantau dan mendisiplinkan 
manajer agar lebih terfokus pada nilai perusahaan. Selain itu, kepemilikan institusional memiliki kemampuan untuk mengendalikan pihak manajemen melalui proses pengawasan secara efektif sehingga dapat mengurangi manajemen laba. Persentase saham tertentu yang dimiliki oleh institusi dapat mempengaruhi proses penyusunan laporan keuangan yang tidak menutup kemungkinan terdapat akrualisasi sesuai kepentingan pihak manajemen (Boediono, 2005). Del Guercio dan Hawkins (1999) dan Hartzell dan Starks (2003) dalam Cornett et al. (2006) menemukan adanya bukti yang menyatakan bahwa tindakan pengawasan yang dilakukan oleh sebuah perusahaan dan pihak investor institusional dapat membatasi perilaku manajer. Dengan demikian, tindakan pengawasan perusahaan yang dilakukan oleh pihak kepemilikan institusional dapat mendorong manajer untuk lebih memfokuskan perhatiannya terhadap kinerja perusahaan sehingga akan membatasi perilaku manajer di dalam manajemen laba.

Penelitian yang dilakukan oleh Charitou et al. (2007), juga menemukan adanya suatu hubungan positif dan signifikan antara konsentrasi kepemilikan institusional dan manajemen laba. Fan dan Wong (2002); Donnelly dan Lynch (2002); Firth et al. (2007), menemukan bahwa dampak konsentrasi kepemilikan menyebabkan asimetri informasi bagi manajer dan investor yang menimbulkan motivasi bagi manajer untuk melakukan manajemen laba. Penelitian oleh Wedari (2004), menyatakan bahwa kepemilikan institusional berpengaruh positif terhadap manajeman laba, sedangkan Sriwedari (2009), menemukan bahwa kepemilikan institusional memberikan pengaruh negatif dan tidak signifikan terhadap manajemen laba.

Di Indonesia, pembentukan komite audit merupakan persyaratan yang bersifat mandatory bagi semua perusahaan yang terdaftar di Bursa Efek Indonesia. Persyaratan tersebut sesuai dengan peraturan yang dikeluarkan oleh BAPEPAM No.IX.I.5 tahun 2004, yang menyatakan bahwa emiten atau perusahaan publik wajib memiliki komite audit. Kepemilikan institusional di Indonesia cenderung bersifat konsentrasi kepemilikan. Tipe kepemilikan terkonsentrasi banyak ditemukan di sebagian besar negara di Asia, khususnya negara berkembang termasuk Indonesia. Pada tipe ini masalah yang sering timbul adalah konflik kepentingan antara pemegang saham mayoritas dengan pemegang saham minoritas (Fan dan Wong, 2002). Peran komite audit diharapkan dapat mengendalikan perilaku oportunistik manajemen dalam mengelola laba. Fan dan Wong (2002) melakukan penelitian yang memfokuskan pada hubungan antara struktur kepemilikan perusahaan dan kualitas informasi akuntansi di tujuh negara Asia Timur termasuk Indonesia dengan menggunakan keinformatifan earnings akuntansi sebagai ukuran kualitas informasi akuntansi. Fan dan Wong (2002) menemukan bahwa kepemilikan terkonsentrasi menciptakan masalah agensi antara pemegang kendali (controlling owners) dengan outside investors. Konsekuensinya, pemegang kendali diduga melaporkan informasi akuntansi untuk tujuan dirinya sendiri. Dalam hal demikian, kredibilitas laporan earnings menjadi rendah untuk outside investors karena keinformatifan earnings berhubungan secara negatif dan signifikan terhadap derajat perbedaan antara kontrol dari pemilik ultimat dan level kepemilikan ekuitas.

Berdasarkan uraian dalam latar belakang diatas, maka penelitian ini akan mencoba meneliti mengenai kompetensi komite audit, aktivitas komite audit dan kepemilikan institusional terhadap manajemen laba (studi empiris pada perusahaan manufaktur yang terdaftar di Bursa Efek Indonesia), dengan menyertakan leverage, pertumbuhan perusahaan, umur perusahaan, dan ukuran perusahaan sebagai variabel kontrol. 


\section{TELAAH LITERATUR DAN PENGEMBANGAN HIPOTESIS}

Healy dan Wahlen (1999), menyatakan bahwa definisi manajemen laba mengandung beberapa aspek. Pertama, intervensi manajemen laba terhadap pelaporan keuangan dapat dilakukan dengan penggunaan judgment, misalnya judgment yang dibutuhkan dalam mengestimasi sejumlah peristiwa ekonomi di masa depan untuk ditunjukan dalam laporan keuangan, seperti perkiraan umur ekonomis dan nilai residu aset tetap, tanggung jawab untuk pensiun, pajak yang ditangguhkan, kerugian piutang dan penurunan nilai aset. Disamping itu manajer memiliki pilihan untuk metode akuntansi, seperti metode penyusutan dan metode biaya. Kedua, tujuan manajemen laba untuk menyesatkan stakeholders mengenai kinerja ekonomi perusahaan. Hal ini muncul ketika manajemen memiliki akses terhadap informasi yang tidak dapat diakses oleh pihak luar. Lebih lanjut menurut Healy dan Wahlen (1999), manajemen laba terjadi ketika manajer melakukan pertimbangan (judgement) dalam pelaporan keuangan dan penyusunan transaksi untuk mengubah laporan keuangan, dengan tujuan untuk memanipulasi besaran (magnitude) laba kepada beberapa stakeholders tentang kinerja keuangan perusahaan atau untuk mempengaruhi hasil perjanjian (kontrak) yang bergantung pada angka-angka akuntansi yang dilaporkan.

Terdapat dua konsep akrual di dalam manajemen laba, yaitu: discretionary accrual dan non discretionary accrual. Discretionary accrual adalah pengakuan akrual laba atau beban yang bebas, tidak diatur dan merupakan pilihan kebijakan manajemen. Menurut Scott (1997) dalam Surifah (2001) discretionary accrual adalah suatu cara untuk mengurangi pelaporan laba yang sulit dideteksi melalui manipulasi kebijakan akuntansi yang berkaitan dengan akrual, misalnya dengan cara menaikkan biaya amortisasi dan depresiasi, mencatat kewajiban yang besar atas jaminan produk, kontijensi dan potongan harga dan mencatat persediaan yang sudah usang.

Non discretionary accrual adalah pengakuan akrual laba yang wajar, yang tunduk pada suatu standar atau prinsip akuntansi yang berlaku umum. Non discretionary accrual merupakan akrual yang wajar, dan apabila dilanggar akan mempengaruhi kualitas laporan keuangan (tidak wajar), oleh karena itu bentuk akrual yang dianalisis dalam penelitian ini adalah bentuk discretionary accrual yang merupakan akrual abnormal dan merupakan pilihan kebijakan manajemen dalam pemilihan metode akuntansi.

\section{Good Corporate Governance}

Isu utama di dalam penerapan good corporate governance, adalah bagaimana para manajer menyajikan informasi laba kepada pihak-pihak yang berkepentingan untuk melakukan keputusan investasi di dalam suatu perusahaan dan menggunakan informasi tersebut untuk menentukan keputusan investasi tersebut. Secara khusus, keputusan untuk melakukan investasi berkaitan dengan hubungan antara manajemen perusahaan dan para stakeholder, sehingga diperlukan adanya suatu good corporate governance untuk mengendalikan perilaku manajer agar bertindak tidak hanya menguntungkan dirinya sendiri, namun juga harus menyamakan kepentingan antara pemilik perusahaan dan manajer.

Sasaran utama corporate governance adalah: (a) secara internal yaitu adanya sistem dan struktur yang 
menjamin berjalannya fungsi dari organ-organ perusahaan (RUPS, komisaris dan direksi) secara seimbang. Hal yang berkaitan dengan masalah tersebut antara lain adanya pemenuhan hak-hak pemegang saham secara adil, pengendalian yang efektif oleh dewan komisaris, serta pengelolaan perusahaan yang transparan dan bertanggung jawab oleh direksi, dan (b) secara eksternal menyangkut pemenuhan tanggung jawab perusahaan kepada para pihak yang berkepentingan dengan perusahaan. Hal ini terkait dengan bagaimana perusahaan mengakomodasi kepentingan pihak-pihak tersebut termasuk pemenuhan kewajiban perusahaan untuk taat kepada peraturan yang ada. Untuk merealisasikan sasaran tersebut digunakan empat prinsip utama yaitu : transparansi, akuntabilitas, kewajaran dan responsibilitas yang dilakukan melalui mekanisme internal maupun eksternal. Mekanisme internal, seperti struktur dewan direksi, kepemilikan manajerial, dan kompensasi eksklusif serta mekanisme eksternal meliputi pasar untuk kontrol perusahaan, kepemilikan institusional dan tingkat pendanaan dengan utang.

\section{Pengaruh Kompetensi Komite Audit terhadap Manajemen Laba}

Proporsi anggota komite audit yang merupakan ahli di bidang keuangan dapat meningkatkan fungsi pengawasan pemilik perusahaan (prinsipal) terhadap pihak manajemen (agen). Dengan semakin besar proporsi anggota yang memiliki keahlian di bidang keuangan maka pelaporan keuangan oleh manajemen akan lebih berkualitas. Hal ini disebabkan karena anggota yang memiliki keahlian di bidang keuangan akan lebih mudah dalam mendeteksi adanya manipulasi laba yang dapat menguntungkan manajemen saja. Oleh karena itu, penting bagi anggota komite audit untuk memiliki tingkat kompetensi di bidang keuangan yang mendukung peran pemantauan dewan komisaris.

Chtourou et al.(2001), Xie et al.(2003); Bedard et al. (2004); Carcello, et al. (2006); Dhaliwal et al. (2006); menemukan bahwa komite audit yang mempunyai keahlian di bidang keuangan adalah berpengaruh negatif terhadap manajemen laba. Hal ini mengarah pada hipotesis pertama :

Hipotesis 1 : Kompetensi komite audit berpengaruh negatif terhadap manajemen laba.

\section{Pengaruh Aktivitas Komite Audit terhadap Manajemen Laba}

Keaktifan anggota komite audit diukur dari jumlah rapat yang dilakukan oleh komite audit. Semakin tinggi frekuensi rapat yang diadakan akan meningkatkan keefektivan komite audit dalam mengawasi manajemen manajemen, agar tidak berusaha mengoptimalkan kepentingannya sendiri. Penelitian sebelumnya yang dilakukan oleh Chtourou et al. (2001); Xie et al. (2003), menunjukkan bahwa komite audit yang lebih aktif adalah lebih efektif dalam memantau manajemen laba dan restatement (Abbott et al., 2004). Sharma et al. (2009) dalam Putri (2011), membuktikan bahwa perusahaan yang memiliki komite audit dengan tingkat frekuensi pertemuan yang kecil akan cenderung menghasilkan laporan keuangan yang kurang berkualitas. Sehingga dapat dikatakan bahwa semakin sering rapat komite audit dapat meminimalisasi terjadinya manajemen laba. Pembahasan sebelumnya mengarah ke hipotesis berikut :

Hipotesis 2 : Aktivitas komite audit berpengaruh negatif terhadap manajemen laba.

\section{Pengaruh Kepemilikan Institusional terhadap Manajemen Laba}


Kepemilikan institusional memiliki kemampuan untuk mengendalikan pihak manajemen melalui proses monitoring secara efektif sehingga dapat mengurangi manajemen laba. Persentase saham tertentu yang dimiliki oleh institusi dapat mempengaruhi proses penyusunan laporan keuangan yang tidak menutup kemungkinan terdapat akrualisasi sesuai kepentingan pihak manajemen (Boediono, 2005).

Cornertt et al. (2006) menyimpulkan bahwa tindakan pengawasan perusahaan oleh kepemilikan institusional dapat mendorong manajer untuk lebih memfokuskan perhatiannya terhadap kinerja perusahaan sehingga akan mengurangi perilaku opportunistik atau mementingkan diri sendiri. Balsam et al.(2002) dalam Siregar dan Utama (2005) menemukan adanya hubungan negatif antara discretionary accrual yang tidak diekspektasi dengan imbal hasil saham di sekitar tanggal pengumuman, dimana hubungan negatif tersebut bervariasi tergantung tingkat kecanggihan investor, dimana reaksi pasar dari investor yang lebih canggih mendahului investor yang tidak canggih.

Hipotesis 3 : Kepemilikan institusional berpengaruh negatif terhadap manajemen laba.

\section{METODE PENELITIAN}

Populasi dalam penelitian ini adalah seluruh perusahaan manufaktur yang listing di Bursa Efek Indonesia (BEl) per tanggal 1 Januari 2007 sampai dengan 31 Desember 2012.

Teknik pengambilan sampel dalam penelitian ini dilakukan dengan metode purposive sampling dengan tujuan untuk mendapatkan sampel yang representative sesuai dengan kriteria yang ditentukan, yaitu

perusahaan manufaktur yang terdaftar secara konsisten di Bursa Efek Indonesia per 1 Januari 2007 sampai dengan per 31 Desember 2012 serta menerbitkan laporan tahunan untuk periode tahun 2007 sampai tahun 2012 yang tersedia pada Indonesian Capital Market Directory (ICMD), www.idx.co.id ataupun website perusahaan.

\section{Definisi Operasional dan Pengukuran Variabel Variabel Dependen}

Dalam penelitian ini, variabel dependen yang digunakan adalah manajemen laba yang diproksikan dengan discretionary accrual. Discretionary accrual digunakan untuk pengukuran manajemen laba oleh banyak peneliti sebelumnya (Dechow et a.l, 1995; Guayet et al., 1996; Kasznik, 1999; Bartov et al., 2000; dan Kothari, 2001) dalam Lin et al., (2009). Model Jones yang dimodifikasi telah digunakan secara ekstensif dalam penelitian sebelumnya untuk mengukur manajemen laba. Jones (1991), DeFond dan Jiambalvo, (1994) dan Butler et al., (2004) dalam Lin et al., (2009), menggunakan model Jones yang dimodifikasi sebagai proksi untuk manajemen laba. Model ini digunakan karena dinilai merupakan model yang paling baik dalam mendeteksi manajemen laba (Siallagan dan Machfoedz, 2006) dalam Putri (2011).

Menghitung total accrual dengan persamaan :

Total Accrual $(T A C)=$ laba bersih setelah pajak (net income) - arus kas operasi (cash flow from operating)

Menghitung nilai accrual dengan persamaan regresi linear berganda yang berbasis ordinary least square 
(OLS) sebagai berikut :

$$
\text { TACt } / \text { At-1 }=\alpha 1(1 / \text { At-1 })+\alpha 2(\Delta R E V t / \text { At-1 })+\alpha 3(\text { PPEt } / \text { At-1 })+e
$$

Keterangan :

TAC $_{\mathrm{t}} \quad$ : Total accrual perusahaan i pada periode $\mathrm{t}$

$\mathrm{A}_{\mathrm{t}-1} \quad$ : Total aset untuk sampel perusahaan i pada tahun $\mathrm{t}-1$

REV $_{t} \quad$ : Perubahan penjualan perusahaan i dari tahun $\mathrm{t}-1$ ke tahun $\mathrm{t}$

$\mathrm{PPE}_{\mathrm{t}} \quad$ : Aset tetap (property, plant and equipment) perusahaan tahun $\mathrm{t}$

Dengan menggunakan koefisien regresi di atas, kemudian dilakukan perhitungan nilai non discretionary accrual (NDA) dapat dihitung dengan rumus :

NDAt $=a 1(1 /$ At-1 $)+a 2((\triangle R E V t-\triangle R E C t) / A t-1)+a 3($ PPEt $/$ At-1 $)$

Keterangan :

$\mathrm{NDA}_{\mathrm{t}} \quad$ : Non discretionary accrual pada tahun $\mathrm{t}$

$\triangle$ REC $_{\mathrm{t}} \quad$ : Perubahan piutang perusahaan i dari tahun $\mathrm{t}-1$ ke tahun $\mathrm{t}$

a: $\quad$ total accrual

Menghitung nilai discretionary accrual (DAC) dengan persamaan :

$$
\mathrm{DACt}=(\mathrm{TACt} / \mathrm{At}-1)-\mathrm{NDAt}
$$

Keterangan :

DAC $_{\mathrm{t}} \quad: \quad$ Discretionary accrual pada perusahaan i pada periode $\mathrm{t}$

\section{Variabel Independen}

\section{Kompetensi komite audit}

Komite audit yang terdiri dari paling tidak satu anggota yang memiliki kompetensi di bidang keuangan akan lebih efektif dalam mendeteksi salah saji material dalam pelaporan keuangan. Variabel ini diukur dengan cara mencari persentase dari jumlah anggota komite audit yang mempunyai keahlian di bidang keuangan terhadap jumlah anggota komite audit keseluruhan.

\section{b. Aktivitas komite audit}

Dalam penelitian ini aktivitas komite audit dinyatakan dalam frekuensi kehadiran rapat komite audit yang dilakukan setiap tahun. Komite audit wajib mengadakan pertemuan minimal dalam setahun sekurangkurangnya sama dengan ketentuan minimal rapat dewan komisaris yang ditetapkan dalam angaran dasar, untuk mendiskusikan pelaporan keuangan dengan auditor eksternal. Variabel ini diukur dari jumlah rapat yang dilakukan oleh komite audit dalam tahun berjalan.

\section{c. Kepemilikan institusional}

Kepemilikan institusional merupakan jumlah saham perusahaan yang dimiliki oleh pemegang saham

Jurnal Akuntansi Indonesia 
institusional. Kepemilikan institusional diukur dengan jumlah proporsi saham yang dimiliki dibagi dengan jumlah saham yang telah diterbitkan oleh perusahaan.

\section{Variabel Kontrol}

\section{Leverage (LEV)}

LEV dirumuskan dengan utang jangka panjang ditambah utang lancar dibagi dengan total aset. Pertumbuhan Perusahaan (SALESGROWTH)

SALESGROWHT dihitung dari total penjualan pada tahun t dikurangi total penjualan tahun $\mathrm{t}-1$ dibagi dengan total penjualan tahun $\mathrm{t}$.

Umur perusahaan (AGE)

AGE diukur berdasarkan pada jumlah tahun sejak perusahaan didirikan.

Ukuran Perusahaan (LSIZE)

LSIZE diproksikan dengan logaritma natural dari total aset perusahaan pada akhir tahun

\section{Perumusan Model Penelitian}

Model yang digunakan untuk menguji hipotesis dalam penelitian ini adalah model umum persamaan regresi berganda. Model dalam penelitian ini adalah sebagai berikut :

$$
\text { DAC = a0 + } a 1 \text { ACFIN + } a 2 \text { ACM + } a 3 \text { INV + + a4SALESGROWTH + a5AGE + a6 LSIZE+e }
$$

Keterangan :

\section{DAC}

$\boldsymbol{a}_{0}$

$a_{1,2,3,4,5,6}$

INV

LEV

SALESGROWTH

AGE

LSIZE

e
: Ukuran manajemen laba (discretionary accrual)

: Konstanta

: Koefisien variabel

Jumlah saham yang dimiliki oleh pemegang saham institusional dibagi dengan total saham yang diterbitkan.

: (utang jangka panjang + utang lancar) dibagi dengan total aset. Total penjualan pada tahun t dikurangi total penjualan tahun t-1 dibagi dengan total penjualan tahun t.

: Jumlah tahun sejak perusahaan didirikan.

: Nilai logaritma natural total aset perusahaan pada akhir tahun.

: errorterm

\section{HASIL DAN PEMBAHASAN}

Penelitian ini dilakukan pada perusahaan manufaktur yang terdaftar di Bursa Efek Indonesia (BEI) secara konsisten melaporkan laporan keuangan pada tahun 2007 sampai dengan 2012. Berdasarkan metode purposive sampling, maka jumlah sampel yang digunakan dalam penelitian ini adalah sebanyak 50 perusahaan sampel. Periode pengamatan untuk pengujian hipotesis adalah tahun 2007 - 2012, sehingga pooled data untuk 6 periode sebesar 300 sampel (50x6).

\section{Statistik Deskriptif}


Hasil analisis statistik deskriptif untuk masing-masing variabel dalam penelitian ini dapat dilihat pada tabel 1.

\section{Uji Kelayakan Model (Uji Asumsi Klasik)}

Model regresi akan dinyatakan baik dan dapat dilakukan jika memenuhi uji asumsi klasik yaitu uji normalitas, uji multikolinearitas, uji heteroskesastisitas. Dan penelitian ini telah memenuhi uji asumsi klasik, seperti terlihat dalam tabel 2.

\section{Pengujian Hipotesis}

Setelah dilakukan uji asumsi klasik dan goodness of fit, maka tahap selanjutnya dilakukan pengujian hipotesis.

\section{Pengujian Hipotesis 1}

Berdasarkan hasil pengujian hipotesis ini, diperoleh t hitung sebesar -2,121 dengan signifikansi 0,035. Hal ini mengindikasikan bahwa kompetensi komite audit berpengaruh negatif dan signifikan pada alpha 5\% terhadap manajemen laba yang diproksikan dengan discretionary accrual, sehingga hipotesis pertama (H1) diterima. Hal ini berarti kompetensi komite audit (ACIND) berpengaruh negatif dan signifikan terhadap manajemen laba yang diproksikan dengan discretionary accrual (DAC).

Proporsi anggota komite audit yang merupakan ahli di bidang akuntansi atau keuangan juga dapat meningkatkan fungsi pengawasan pemilik perusahaan (prinsipal) terhadap pihak manajemen (agen). Dengan semakin besar proporsi anggota yang memiliki keahlian di bidang akuntansi atau keuangan maka pelaporan keuangan oleh manajemen akan lebih berkualitas. Hal ini disebabkan karena anggota yang memiliki keahlian di bidang akuntansi atau keuangan akan lebih mudah dalam mendeteksi adanya manipulasi laba yang dapat menguntungkan manajemen saja. Oleh karena itu, penting bagi anggota komite audit untuk memiliki tingkat kompetensi di bidang akuntansi atau keuangan yang mendukung peran pemantauan dewan komisaris.

Rekomendasi tentang corporate governance, yang dikeluarkan oleh Blue Ribbon Report, berpendapat bahwa anggota komite audit seharusnya mempunyai pengalaman di bidang keuangan (Xie, et al., 2003. Penelitian yang dilakukan oleh Chtourou et al. (2001); Xie, et al. (2003); Bedard, et al. (2004); Carcello et al. (2006), menemukan bahwa komite audit yang mempunyai keahlian di bidang keuangan, berpengaruh negatif terhadap manajemen laba.

\section{Pengujian Hipotesis 2}

Berdasarkan hasil pengujian hipotesis ini, diperoleh t hitung sebesar -1,380 dengan signifikansi 0,002. Hal ini mengindikasikan bahwa independensi komite audit berpengaruh negatif dan signifikan pada alpha 5\% terhadap manajemen laba yang diproksikan dengan discretionary accrual, sehingga hipotesis kedua $(\mathrm{H} 2)$ diterima. Hal ini berarti kompetensi komite audit (ACIND) berpengaruh negatif dan signifikan terhadap manajemen laba yang diproksikan dengan discretionary accrual (DAC). 
Komite audit diharapkan harus aktif untuk melakukan tugas mereka. Keaktifan anggota komite audit diukur dari jumlah rapat yang dilakukan oleh komite audit. Semakin tinggi frekuensi rapat yang diadakan akan meningkatkan keefektivan komite audit dalam mengawasi manajemen manajemen, agar tidak berusaha mengoptimalkan kepentingannya sendiri.

Penelitian sebelumnya yang dilakukan oleh Chtourou et al. (2001); Xie et al. (2003), menunjukkan bahwa komite audit yang lebih aktif adalah lebih efektif dalam memantau manajemen laba dan restatement (Abbott et al., 2004). Penelitian Lin et al. (2009), juga menyatakan bahwa aktivitas komite audit merupakan faktor penting dalam membatasi kecenderungan manajer untuk melakukan manajemen laba.

\section{Pengujian Hipotesis 3}

Berdasarkan hasil pengujian hipotesis ini, diperoleh t hitung sebesar -0,012 dengan signifikansi 0,603. Dengan signifikansi yang jauh diatas 0,05, maka hipotesis ketiga (H3) tidak dapat diterima atau hipotesis ditolak. Hal ini berarti kepemilikan institusional (INV) tidak berpengaruh terhadap manajemen laba yang diproksikan dengan discretionary accrual (DAC).

Penelitian ini menunjukkan bahwa kepemilikan institusional tidak dapat menjalankan perannya secara efektif. Penelitian yang dilakukan oleh Porter (1992) dalam (Midiastuty dan Mas'ud 2003), menunjukkan bahwa institusional adalah pemilik yang lebih memfokuskan pada current earnings. Akibatnya manajer terpaksa untuk melakukan tindakan yang dapat meningkatkan laba jangka pendek, misalnya dengan melakukan manipulasi laba. Pandangan yang sama juga dikemukakan oleh Cornett et al. (2006) yang menyatakan bahwa kepemilikan institusional akan membuat manajer merasa terikat untuk memenuhi target laba dari para investor, sehingga mereka akan tetap cenderung terlibat dalam tindakan manipulasi laba.

Hasil penelitian ini bertentangan dengan penelitian yang dilakukan oleh Wedari (2004), yang menyatakan bahwa kepemilikan institusional berpengaruh positif dan signifikan terhadap manajeman laba, serta penelitian yang dilakukan oleh Charitou et al. (2007) yang menemukan adanya suatu hubungan positif dan dan signifikan antara konsentrasi kepemilikan institusional dan manajemen laba. Sebaliknya, hasil penelitian ini sejalan dengan penelitian yang dilakukan oleh Siregar dan Utama (2005) yang menemukan bahwa kepemilikan institusional dan tiga variabel praktek GCG tidak berpengaruh signifikan terhadap manajemen laba, serta penelitian yang dilakukan oleh Sriwedari (2009) yang menyatakan bahwa kepemilikan institusional tidak berpengaruh terhadap manajemen laba.

\section{Pengujian variabel-variabel kontrol}

Dalam penelitian ini leverage (LEV) merupakan variabel kontrol. Berdasarkan nilai t hitung sebesar -0,023 dengan signifikansi 0.003 . Dengan demikian, hasil pengujian tersebut menunjukkan bahwa leverage (LEV) berpengaruh positif dan signifikan terhadap manajemen laba (DAC) dengan tingkat signifikansi di bawah 0.05.

Variabel kontrol yang kedua adalah pertumbuhan perusahaan (SALESGROWTH). Berdasarkan nilai $t$ hitung adalah sebesar 1,221 dengan signifikansi 0,223. Dengan signifikansi yang jauh diatas 0.05, maka mengindikasikan bahwa tidak terdapat pengaruh pertumbuhan perusahaan (SALESGROWTH) terhadap 
manajemen laba (DAC).

Variabel kontrol yang ketiga adalah umur perusahaan (AGE). Berdasarkan nilai t hitung adalah sebesar 1,847 dengan signifikansi 0,046. Dengan demikian, hasil pengujian tersebut menunjukkan bahwa umur perusahaan (AGE) berpengaruh negatif dan signifikan terhadap manajemen laba (DAC) dengan tingkat signifikansi di bawah 0.05 .

Variabel kontrol yang keempat atau terakhir adalah ukuran perusahaan (LNSIZE) yang diproksikan dengan hasil logaritma natural total aset perusahaan. Berdasarkan nilai t hitung sebesar 1,461 dengan signifikansi 0,045. Dengan demikian, hasil pengujian tersebut menunjukkan bahwa ukuran perusahaan (LSIZE) berpengaruh positif dan signifikan terhadap manajemen laba dengan tingkat signifikansi di bawah 0.05 .

\section{SIMPULAN}

Tujuan utama penelitian ini adalah untuk mendapatkan bukti empiris kompetensi komite audit, aktivitas komite audit dan kepemilikan institusional terhadap manajemen laba. Berdasarkan hasil penelitian dan pembahasan yang telah dilakukan mengenai kompetensi komite audit, aktivitas komite audit dan kepemilikan institusional terhadap manajemen laba, maka dapat diambil kesimpulan bahwa kompetensi komite audit, aktivitas komite audit dapat mengurangi tindakan manajemen laba yang dilakukan oleh manajer perusahaan. Sebaliknya, kepemilikan institusional tidak dapat mengurangi tindakan manajemen laba yang dilakukan oleh manajer perusahaan. Dengan demikian hasil penelitian ini berimplikasi untuk mendorong riset akuntansi keuangan dan good corporate governance untuk menganalisis lebih lanjut mengenai variabel lain yang berpengaruh terhadap manajemen laba sehingga akan dapat mengatasi permasalahan yang sering muncul antara pemilik perusahaan (principal) dengan manajer (agent), dan akan mewujudkan suatu good corporate governance.

\section{DAFTAR PUSTAKA}

Anderson, K.L., Deli, D.N., and Gillan, S.T. 2003. "Board of Directors, Audit Committees, and The Information Content of Earnings." Working Paper.

Antle, R. and Nalebuff, B. 1991. “Conservatism and Auditor-Clien Negotiations." Journal of Accounting Research 29, p. 31-54.

BAPEPAM. 2004. Peraturan IX.1.5. 2004 tentang "Pembentukan dan Pedoman Pelaksanaan Kerja Komite Audit". http://www.bapepamlk.depkeu.go.id/old/hukum/peraturan/emiten/. Diakses tanggal 14 Desember 2009.

Bartov, A. and B. Eli. 1993. "The Timing of Asset Sales and Earnings Manipulation". The Accounting Review, October, p. 653-668.

Beattie, V., S. Brown, D. Ewers, B. John, S. Manson, D. Thomas, and M. Turner. 1994. “Extraordinary Items and Income Smoothing : A Positive Accounting Approach." Journal of Business Finance and Accounting, 21 (6), September, p. 791-811.

Bedard, J., Chtourou, S.M., and Courteau, L. 2004. "The Effect of Audit Committee Expertise, Independence, and 
Activity on Aggressive Earnings Management." Auditing: A Journal of Practice and Theory, 23 (2):1335.

Blue Ribbon Committee (BRC). 1999. "Audit Committee Characteristics and Restatements: A Study of the

Efficacy of Certain Blue Ribbon Committee Recommendations." New York : New York Stock Exchange and National Association of Securities Dealer.

Boediono, Gideon SB. 2005. “Kualitas Laba : Studi Pengaruh Mekanisme Corporate Governance dan Dampak Manajemen Laba dengan Menggunakan Analisis Jalur." Simposium Nasional Akuntansi VIII.

Bradbury, M. E., Mak, Y. T., and Tan, S. M. 2004. "Board Characteristics, Audit Committee Characteristics and Abnormal Accruals", Working Paper, Unitec New Zealand and National University of Singapore.

Carcello, J. V., and Neal, T. L. 2000. "Audit Committee Compositian and Auditor Reporting." The Accounting Review, Vol. 75, No. 4, October 2000.

Carcello, J.V., Hollingsworth, C.W., Klein, A., and Neal, T.L. 2006. “Audit Committee Financial Expertise, Competing Corporate Governance Mechanisms, and Earnings Management". http://papers.ssrn.com/. Diakses tanggal 5 Januari 2011.

Charitou, A., Lambertides, N., and Trigeorgis, L. 2007. “Earnings Behaviour of Financially Distressed Firms: The Role of Institutional Ownership". Abacus. 43(3): 271296.

Chtourou, SM., Jean Bedard, and Lucie Courteau. 2001. "Corporate Governance and Earnings Management." http://papers.ssrn.com/. Diakses tanggal 5 Januari 2011.

Cornett M.M., J Marcuss, Saunders, and Tehranian H. 2006. “Earnings Management, Corporate Governance, and True Financial Performance." http://papers.ssrn.com/. Diakses tanggal 5 Januari 2011.

Dhaliwal, D.S., Naiker, V., and Navissi, F. 2006. “Audit Committee Financial Expertise, Corporate Governance and Accruals Quality: An Empirical Analysis." http://papers.ssrn.com/. Diakses tanggal 5 Januari 2011.

Donnelly, R. and Lynch, C. 2002. "The Ownership Structure of U.K. Firms and The Informativeness of Accounting Earnings." Accounting and Business Research, 32 (4):245258.

Dye, R. A., "Informationally Motivated Auditor Replacement." Journal of Accounting \& Ecconomics 14, 1991, p. 347-374.

Fan, J.P.H., and Wong, T.J. 2002. "Corporate Ownership Structure and The Informativeness of Accounting Earnings in East Asia." Journal of Accounting \& Economics. 33(3): 401425.

FCGI. 2001. Peranan Dewan Komisaris dan Komite Audit dalam Pelaksanaan Corporate governance (Tata Kelola Perusahaan). Jilid II, Edisi 2.

Firth, M., Fung, P.M.Y., and Rui, O. M. 2007. "Ownership, Two Tier Board Structure, and The Informativeness of Earnings Evidence From China." Journal of Accounting and Public Policy. 26(4): 463496.

Fisher, M. and Rosenzweigh, K. 1995. "Attitudes of Students and Accounting Practitioners Concerning The Ethical Acceptability of Earnings Management." Journal of Business Ethics. Vol 14, No. 6, pp.433-444.

Handayani, RR. Sri, dan Agustono Dwi Rachadi. "Pengaruh Ukuran Perusahaan terhadap Manajemen Laba". Jurnal Bisnis dan Akuntansi. Vol.11, No.1, April 2009, HIm 33-56.

Healy, P.M. and Wahlen, J. 1999. "A Review Of The Earnings Management Literature and Its Implications For Standard Setting." Accounting Horizons, Vol 13, No. 4, pp. 365-383. 
Hendricksen, E.S., and Michael F.Van Breda. 1992. "Accounting Theory". Fifth Edition. Richard D. Irwin, Boston. Jensen, Michael C. and W.H. Meckling. 1976. "Theory of The Firm : Managerial Behaviour, Agency Cost and Ownership Structure." Journal of Financial Economics 3. pp.305-360.

Kaihatu, Thomas S. 2005. "Good Corporate Governance dan Penerapannya di Indonesia." http://www.petra. ac.id/puslit/journals/dir.php. Diakses tanggal 22 Februari 2008.

Klein, A. 2002. "Audit Committee, Board of Director Characteristic, and Earnings Management." http://papers. ssrn.com/. Diakses tanggal 20 Januari 2011.

Kothari, S.P., (2001). “Capital Markets Research in Accounting... Journal of Accounting and Economics, 31:105231.

Kouki, Mondher. and Moncef Guizani. 2009. "Ownership Structure and Dividend Policy Evidence from the Tunisian Stock Market. European Journal of Scientific Research. http://www.eurojournals.com/ejsr.htm. Diakses tanggal 20 Januari 2011.

Lai, L.H. 2005. "Are Independent Directors Effective in Lowering Earnings Management in China." A Dissertation. Texas A \&M University. pp. 1-85.

Lastanti, Hexana Sri. 2005. “Hubungan Struktur Corporate Governance dengan Kinerja Perusahaan dan Reaksi Pasar." Konferensi Nasional Akuntansi.

Lin, J.W., Li, J.F. and Yang, S.Y. 2006. “The Effect of Audit Committee Performance on Earnings Quality. " Managerial Auditing Journal, 21 (9):921933.

Lin, Philip T., Marion R. Hutchinson, and Majella Percy. 2009. “The Role of The Audit Committee and Institutional Investors in Constraining Earnings Management : Evidence from Chinese Firms Listed in Hong Kong." Working Paper. Queensland University of Technology and Griffith University.

Morris, R.D. 1987. "Signaling, Agency Theory and Accounting Policy Choice." Accounting and Business Research, Vol 18, No. 69, pp. 47-56.

Murni, Sri dan Andriana. 2007. “Pengaruh Insider Ownership, Institusional Investor, Dividend Payments, dan Firm Growth terhadap Kebijakan Hutang Perusahaan (Studi Kasus pada Perusahaan Manufaktur yang terdaftar di Bursa Efek Jakarta)." Jurnal Akuntansi dan Bisnis. 7(1): 15-24.

Ningsaptiti, Restie. 2010. "Analisis Pengaruh Ukuran Perusahaan dan Mekanisme Corporate Governance terhadap Manajemen Laba". Skripsi S1. Tidak Dipublikasikan. Universitas Diponegoro Semarang.

Destika Maharani. 2011. "Pengaruh Karakteristik Komite Audit terhadap Manajemen Laba”. Skripsi S1. Tidak Dipublikasikan. Universitas Diponegoro Semarang.

Richardson V.J. 1998. "Information Asymetry and Earnings Management Some Evidence.” http:/www.ssrn.com. Diakses tanggal 12 Januari 2011.

Rizae, Zabihollah. 2007. “Corporate Governance Post-Sarbanes-Oxley : Regulations, Requirements, and Integrated Processes". Wiley. Canada.

Sabeni, A. 2005. "Peran Akuntan dalam Menegakkan Prinsip Good Corporate Governance pada Perusahaan di Indonesia (Tinjauan Perspektif Teori Keagenan)". http://eprints.undip.ac.id/333/1/Arifin.pdf. Diakses tanggal 1 Desember 2009.

Scheileifer and Vishny. 1997. "Corporate Governance Principles of Corporate Governance in Greece" An 
International Revie, Vol 9, Issue 2.

Siregar, Sylvia Veronica N.P dan Siddharta Utama. 2005. “Pengaruh Struktur Kepemilikan, Ukuran Perusahaan, dan Praktek Corporate Governance Terhadap Pengelolaan Laba (Earnings Management).” Proceeding Simposium Nasional

Sriwedari, Tuti. 2009. "Mekanisme Good Corporate Governance, Manajemen Laba dan Kinerja Keuangan Perusahaan Manufaktur di Bursa Efek Indonesia". Tesis S2. Tidak Dipublikasikan. Universitas Sumatera Utara, Medan.

Surifah. 2001. "Studi tentang Indikasi Unsur Manajemen Laba pada Laporan Keuangan Perusahaan Publik di Indonesia." Jurnal Akuntansi Auditing Indonesia,

Wahidawati. 2001. "Pengaruh Kepemilikan Manajerial dan Kepemilikan Institusional pada kebijakan Hutang Perusahaan : Sebuah Perspektif Theory Agency". Simposium Akuntansi Nasional IV.

Watts, Ross L. and Jerold L. Zimmerman. 1990. "Positive Accounting Theory : a Ten Year Perspective." The Accounting Review, Vol.65. No.1. January, p .31-156.

Wedari, L.K. 2004. “Analisis Pengaruh Proporsi Dewan Komisaris dan Keberadaan

Worthy, Ford S. 1984. “Manipulating Profits: How It Done." Fortune, June 25,50-54.

Xie, B., Davidson, W.N. and DaDalt, P.J. 2003. "Earnings Management and Corporate Governance: The Role of The Board and The Audit Committee." Journal of Corporate Finance, 9 (3):295316.

Yang, J.S. and Krishnan, J. 2005. "Audit Committees and Quarterly Earnings Management." International Journal of Auditing, 9 (3):201219.

\section{LAMPIRAN}


Tabel 1

Statistik Deskriptif

\begin{tabular}{lcrrrr}
\hline & N & Minimum & Maximum & \multicolumn{1}{c}{ Mean } & \multicolumn{1}{c}{$\begin{array}{c}\text { Std. } \\
\text { Deviation }\end{array}$} \\
\hline DAC & 300 & $-0,514$ & 0,605 & 0,003 & 0,106 \\
\hline ACFIN & 300 & 0,250 & 1,000 & 0,550 & 0,241 \\
\hline ACM & 300 & 2,000 & 24,000 & 6,200 & 3,726 \\
\hline INV & 300 & 0,000 & 0,889 & 0,269 & 0,282 \\
\hline LEV & 300 & 0,038 & 3,392 & 0,508 & 0,447 \\
\hline SALESGROWTH & 300 & $-896,452$ & 0,982 & $-2,958$ & 51,763 \\
\hline AGE & 300 & 6,000 & 79,000 & 33,840 & 13,440 \\
\hline LSIZE & 300 & 23,082 & 31,612 & 27,955 & 1,745 \\
\hline Valid N (listwise) & 300 & & & &
\end{tabular}

Sumber : Data sekunder yang diolah, 2013

Tabel 2

Ringkasan Hasil Uji Asumsi Klasik atas Pengujian Hipotesis Pengaruh Kompetensi Komite Audit, Aktivitas Komite Audit dan Kepemilikan Institusional terhadap Manajemen Laba

\begin{tabular}{|l|c|c|}
\hline Variabel independen dan kontrol & Tolerance & VIF \\
\hline Hasil Pengujian Multikolonieritas & 0,979 & 1,021 \\
\hline - Kompetensi Komite Audit & 0,894 & 1,119 \\
- Aktivitas Komite Audit & 0,828 & 1,208 \\
- Kepemilikan Institusional & 0,819 & 1,221 \\
- Leverage & 0,991 & 1,009 \\
- Pertumbuhan Perusahaan & 0,823 & 1,215 \\
- Umur Perusahaan & 0,799 & 1,252 \\
- Ukuran Perusahaan & Sig. t-test & \\
\hline Hasil Pengujian Heteroskedastisitas (Glejser test) & 0,817 & \\
\hline - Kompetensi Komite Audit & 0,119 & \\
- Aktivitas Komite Audit & 0,320 & \\
- Kepemilikan Institusional & 0,640 & \\
- Leverage & 0,531 & \\
- Pertumbuhan Perusahaan & 0,697 & \\
- Umur Perusahaan & 0,579 & \\
- Ukuran Perusahaan & & \\
\hline Pengujian Normalitas Residual & 0,442 & \\
\hline - Kolmogorov-Smirnov test & & \\
\hline N = 300 & & \\
\hline
\end{tabular}

Sumber : Data Sekunder yang Diolah, 2013 


\section{Tabel 3}

Ringkasan Pengujian Hipotesis Pengaruh Kompetensi Komite Audit, Aktivitas Komite Audit dan Kepemilikan Institusional terhadap Manajemen Laba

\begin{tabular}{lccc}
\hline Variabel independen dan kontrol & & & \\
\hline Pengujian Hipotesis & Coefficient & t value & Sig. \\
\hline - Constant & $-0,140$ & $-1,316$ & 0,189 \\
- Kompetensi Komite Audit & $-0,054$ & $-2,121$ & $0,035^{*}$ \\
- Aktivitas Komite Audit & $-0,169$ & $-1,380$ & $0,02^{*}$ \\
- Kepemilikan Institusional & $-0,012$ & $-0,521$ & 0,603 \\
- Leverage & 0,000 & 0,023 & $0,003^{*}$ \\
- Pertumbuhan Perusahaan & 0,000 & $-1,221$ & 0,223 \\
- Umur Perusahaan & 0,001 & 1,847 & $0,046^{*}$ \\
- Ukuran Perusahaan & 0,006 & 1,461 & $0,045^{*}$ \\
\hline R Square & 0,053 & & \\
Adjusted R Square & 0,330 & & \\
F Statistik & 2,331 & & \\
Signifikansi F Statistik & $0.000^{*}$ & & \\
\hline Variabel dependen : Manajemen Laba (discretionary accrual) & & \\
N = 300 & & \\
*) tingkat signifikansi 5\% & & \\
\hline
\end{tabular}

Sumber : Data Sekunder yang Diolah, 2013 